\title{
The Influence of Human Resources Competency and Performance Management Systems towards Performance Employee Hotel Narita Surabaya
}

\author{
Aldy Januar Rakhmadi' ${ }^{1}$, Hermien Tridayanti ${ }^{2}$ \\ Narotama University Surabaya \\ aldyjanuar85@gmail.com
}

\begin{abstract}
The aim of this research to analyze the competence of human resources and performance management System that supported simultane and partial performance of employees. population on this object 40 employess with data retrieval using the questionnaire. This research data analysis using the method of regression with data processing softwere Statistical Package for Social Science (SPSS) V 23.0. research results generate significant influence through partially and simultaneous test with standard $\mathrm{T}$ table of 2.253 . HA = HR competencies had a significant influence on performance of employees obtained the numbers $\mathrm{T}$-count of $5.820, \mathrm{Ha}=$ management system had a significant influence on performance of employees obtained the numbers Tcount of 2.563 , results of $65.7 \%$ R2 means the ability independent variables in explaining dependent variables are very high. so, all of the free variable is able to prove the existence of the influence in the performance of the employees at Narita Hotel Surabaya.
\end{abstract}

Keywords: HR competencies, management system, employees performance

\section{INTRODUCTION}

Surabaya is the one of metropolis city in East Java and second-largest city after Jakarta in Indonesia. The businessman is being actively built new hotels or to update an existing hotel in Surabaya. The phenomenon occurs because of the large number of domestic as well as foreign tourists who come to Surabaya for a vacation or business trip to run. This makes the demand for hotel accommodation increased, so that the addition of a number of hotels providing increasingly necessary. Therefore I take the Narita Hotel Surabaya in the object due to the long-standing hotel so I am interested in researching how the Hotel was able to compete with new hotels stand in surabaya.

The formulation of the problem based on the background of description above, the authors propose a formulation of the problem as follows:

1. What is the competence of human resources and performance management System effect partially on performance of employees?

2. What is the competence of human resources performance management System and the simultaneous effect on performance of employees?

Based on the formulation of the problem above, the author purpose of the study are as follows:

1. To analyze the competence of human resources and performance management System effect partially against the performance of employees.

2. To analyze the Competence of human resources performance management System and the simultaneous effect on performance of employees.

\section{LITERATURE REVIEW}

\subsection{Theory of Competency}

[1] stated that: the competence of existing capacity is someone who could make the person is able to fulfill what is presupposed by the work within an organization so that these organizations able to achieve the expected results.

\subsection{Perfomance Management Sytems}


[2] said that performance management is an the extensive process that requires a leader who is able to define a job, facilitating, and drive performance with the pursuit of timely feedback and constantly focus the attention of everyone at the target end task.

\subsection{Employee Perfomance}

According to Benardin and Russel in [1]stating that: the performance is the result of that in production by a specific job function or activities on a particular job for a certain time period, showing the the quality and quantity of the work

\subsection{Previous Study}

According to the results of research conducted by [3]stated that the results of this study indicate the magnitude of the influence exerted by combinations of the variables the professionalism of teachers and teachers ' perception about the leadership of the principal is $48.6 \%$ while the rest amounted to $51.4 \%$ are affected by other variables not examined. The absence of the interconnectedness of the professionalism that is affected by factors of leadership that is able to affect the performance of the work. The above research using simple regression analysis, including X 1: x 2: competence, Work Discipline, Z1: Professionalisme, Y: Employee Performance. The above research using simple regression analysis, including $\mathrm{X} 1: \mathrm{x} 2$ : competence, Work Discipline, Z1: Professionalisme, Y: Employee Performance.

According to the results of a study conducted by [4]the results of this research are expected to contribute to the discourse of science in the field of human resources management. This is the explanation of the research that describes the relationship between each variable that there are still shortcomings in the performance of the employee. The existence of significant influence of X 1, x 2 with Y, however there are still shortcomings in the performance of the employee. The above research using simple regression analysis, including $\mathrm{X} 1: \mathrm{x} 2$ : training, ability, Y: the performance of employees.

\section{CONCEPTUAL THINKING AND HYPOTHESIS}

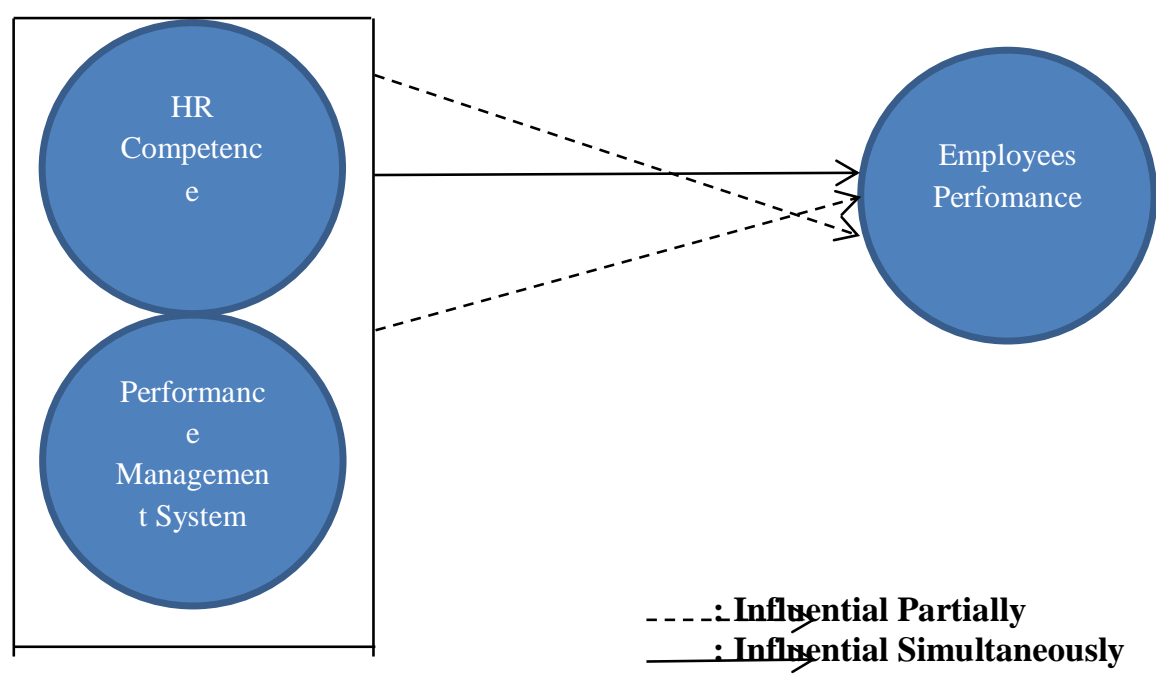

\subsection{Hypothesis}

H1: variable Competence human resources and performance management system was partially significantly influential on performance of employees

H2: variable Competence HUMAN RESOURCES performance management System and the significant effect of simultaneous secaara on performance of employees

\section{METHODOLOGY}

\subsection{Population}

A population is a group of subjects/objects that have the traits or characteristics with different groups of subject/object to another, and that the group will be charged a generalization of results of research [5]. The population in this research totalled 40 . This research using population, by census techniques.

\subsection{Research Design \\ 1. HR Competencies (X 1)}


Competence is a someone who work in the form of the type and level of the different behaviors [6]. According to [7]basic competencies an individual composed of Indicators of competence are:

(1) Informal attitude

(2) Neatness of appearance

(3) Knowledge of employee-owned in every jobdesk

(4) Skill in work

(5) the desired person's Motives in taking an action

(6) the skills to perform specific tasks

2. Performance Management System (X 2)

[8], said that performance management is a process that requires extensive a leader capable of defining a work, facilitate, and encourage the pursuit of performance with feedback in a timely manner and in constant focus the attention of everyone at the target end task in the aspects that are classified in the following indicators:

(1) development of planning employment contract

(2) the management of employees ' working hours arrangements in

(3) a review of employee absences in obedience

(4) the giving of awards from capabilities in providing services to the customers

(5) Training Program to the development of potential employees

(6) the feasibility of the facilities and infrastructure

(7) Logging inventory

\section{Variable dependent}

1. Employee Performance (Y)

According to [9]States that: the performance is basically what is done or not done by the officer in carrying out his work. According to [10],[11] in Performance is the level of achievement of results over the execution of specific tasks. Simanjuntak also reflects the performance of the individual as the level of achievement or the work of someone from a target that should be implemented within a certain period of time. Indicators of Performance, namely:

(1) the quality of work is seen from the level of education

(2) companies need employees who are responsible for

(3) the initiative of employees in completing a job

(4) the efficient completion of the work Time

(5) the thoroughness in doing work

(6) Neatness in doing work

(7) are able to work on new jobs

(8) complete a work in a team

(9) the confidence in serving visitors

(10) the giving impulse, passion, referrals, and support provided by the team leader

\subsection{Data Analysis Techniques}

3.3.1 Validity Test

Test the validity in the research done by comparing the values of rhitung and rtabel for the degree of freedom $(\mathrm{df})=\mathrm{n}-2$, in this case is the number of samples, with the alpha $(\alpha)=0.05$, decision making according to [12]is as follows:

1) if the value of $r$ hitung $>r$ tabel, then the statement or indicator in the study were declared valid.

2 ) if the value of $r$ hitung $<r$ tabel, then the statement or indicator in the study were declared invalid.

\subsubsection{Realibility Test}

Basic decision-making test reliability according to Nunnally in [13] is as follows:

1) if the value of Cronbach Alpha $<0.70$ then it can be inferred that the questionnaire is an indicator of a variable is not reliable.

2) if the value of Cronbach Alpha > 0.70 then it can be inferred that the questionnaire is an indicator of the variables is reliable.

\subsubsection{Ordinal Data Transformation to Interval}

In the regression, statistical procedures require large-scale data interval. Therefore, in this study the ordinal form of initial data must be transferred in advance to data interval. Transformation ordinal data into intervals in this research can be done by using the method of successive intervals (Method of Succesive Interval/MSI). Then manage the data using Ms. Excell.

\subsubsection{Classic Assumption Test}


A classic assumption test is some requirements to be diataati when using a linear regression procedures, such as autocorrelation, multikolinieritas, and heteroskedastisitas data normality [14]

\subsubsection{Multiple Linear Regression Test}

Regression analysis is the analysis to measure the strength of a relationship between two or more variables, and indicates the direction of the relationship between the dependent variable independent variable, where the variable depenen in assuming a random distribution has mean probalistik, whereas the independent variable is assumed to have a fixed value [12]

\section{RESULT AND DISCUSSION}

\subsection{Test Reliability}

Reliability test shows a level of stability, keajegan and accuracy of a measuring instrument or test used to find out the extent to which the measurement is relatively consistent when done restart measurement. This test is used to find out the extent of the person's answers are consistent or stable over time. According to the Arikunto describes the reliability showed an understanding that an instrument is reliable enough to be used as a means of collecting data because the instrument is already good.

Table 4.1 Test Variabel Reliability
Reliability Statistics
\begin{tabular}{|l|l|}
\hline Cronbach's & $\mathrm{N}$ of \\
Alpha & Items \\
\hline, 909 & 23 \\
\hline
\end{tabular}

Source : data output spss

From table 4.6. Note that the value of cronbach alpha for all variables is greater than 0.6. Of the provisions of the previously mentioned then all variables used for research already reliability.

\section{Normality Test}

According to [15]the function of this test try to know regression model of the dependent variable and independent variable or both have a normal distribution or not. If the variable is not distributed normally then the test result statistics will decline. Test the normality of data can be done using One Sample Kolmogorov Smirnov with the provisions in the above 0.05 significant value then the data istributed normally. Whereas if the results of One Sample Kolmogorov Smirnov showed significant values under 0.05 then distributed data is not normal.

To examine there is a normal distribution or not in regresion model can be used graphic analysis (normal probability plot). The results of this graph there are generated when data is spread around the diagonal line and follow the direction of a diagonal line, then the regression model fulfill the assumption of normality of data, otherwise if the data spread away from the diagonal line or do not follow the direction of the line, then the model regression does not meet the assumptions of normality.

Based on the result of SPSS 23 nomality test with normal graph probability plot as follow :

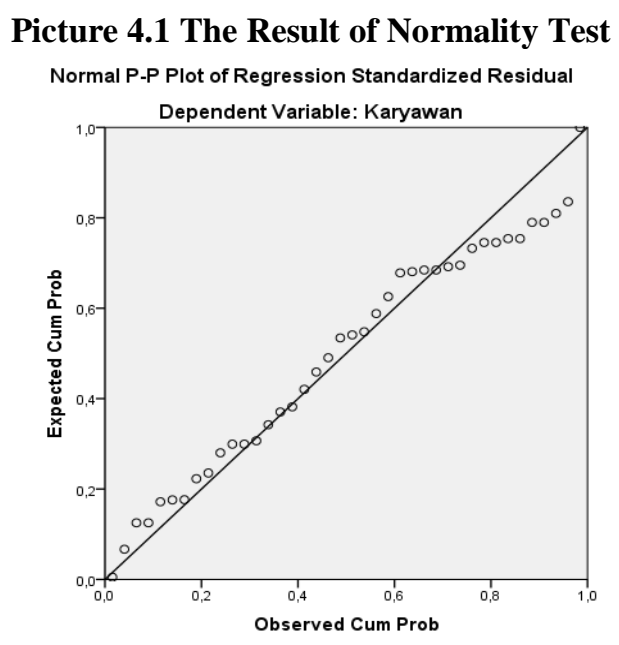

Source : Data output spss

Based on the data above if the result spread out around the diagonal line and heading diagonal line so the regressi model fulfill the normality data assumption. 
4.2 Test Hypothesis

$\mathrm{T}$ test can be used to know the effect of independent variable towards dependent variable. 
Table 4.2 Test Hypothesis (Uji t) Coefficients $^{\mathrm{a}}$

\begin{tabular}{|c|c|c|c|c|c|c|}
\hline \multirow{2}{*}{\multicolumn{2}{|c|}{ Model }} & \multicolumn{2}{|c|}{ Unstandardized Coefficients } & \multirow{2}{*}{\begin{tabular}{|l} 
Stan \\
dard \\
ized \\
Coe \\
ffici \\
ents \\
Beta \\
\end{tabular}} & & \multirow[b]{2}{*}{ Sig. } \\
\hline & & B & $\begin{array}{l}\text { Std. } \\
\text { Error }\end{array}$ & & $\mathrm{t}$ & \\
\hline 1 & $\begin{array}{l}\text { (Cons } \\
\text { tant) }\end{array}$ & 6,001 & 2,664 & & 2 & ,030 \\
\hline & $\mathrm{sdm}$ & 841 & ,144 &, 635 & 5 & 000 \\
\hline & $\begin{array}{l}\text { Siste } \\
\text { mman } \\
\text { ajeme } \\
n\end{array}$ & ,362 & ,136 &, 289 & $\begin{array}{l}6 \\
5 \\
3 \\
3\end{array}$ & ,012 \\
\hline
\end{tabular}

a. Dependent variable employee source : data output spss

Based on the results of a test that looks at the t table 4.11 shows that influence between independent variables the dependent variables against are as follows:

1. Competence of human resources

Partially on performance of employees to find out whether there are significant HUMAN RESOURCE competencies influence on performance of employees, then do the determination of a prior hypothesis, namely:

$\mathrm{HA}=\mathrm{HR}$ competencies had a significant influence on performance of employees.

Once defined the hypothesis then calculated the magnitude of the numbers t-count and the t-table, the result of SPSS gained t-number count of 5.820. Next calculate the t-table with the provision of adequate significance 0.05 . The provision of the t-table numbers then acquired for 1.683 .

After the calculated t-count with a t-table further specifies the criteria the following hypothesis tests:

If $\mathrm{t}$-female $>\mathrm{t}$-table, then the Ha received.

If $\mathrm{t}$-female $<\mathrm{t}$-table, then $\mathrm{HO}$ is rejected.

Based on the results of the above calculation, obtained the numbers t-count of $5.820>\mathrm{t}$-table of 1.683. Therefore, $\mathrm{H} 0$ is rejected and the Ha are received. That is, the competence of HUMAN RESOURCES had a significant influence on performance of employees.

Influence of performance management system partially on performance of employees to find out whether there are significant influence interpersonal on performance of employees, then do the determination of a prior hypothesis, namely:

$\mathrm{HA}=$ management system had a significant influence on performance of employees.

Once defined the hypothesis then calculated the magnitude of the numbers t-count and the t-table, the result of SPSS gained t-number count of 2.563. Next calculate the $t$-table with the provision of adequate significance 0.05 . The provision of the t-table numbers then acquired for 1.683 .

After the calculated t-count with a t-table further specifies the criteria the following hypothesis tests:

If $\mathrm{t}$-female $>\mathrm{t}$-table, then the Ha received.

If $\mathrm{t}$-calculate the $\mathrm{t}$-table $<$, then $\mathrm{HO}$ is rejected.

Based on the results of the above calculation, obtained the numbers $t$-count of $2.563<\mathrm{t}$-table of 1.683. Therefore, $\mathrm{H} 0$ is rejected and the $\mathrm{Ha}$ are received. That is, the performance management system had a significant influence on performance of employees. 


\subsection{Test Simultaneous}

Tabel 4.3 Result of Test Simultaneous

ANOVA $^{\mathrm{a}}$

\begin{tabular}{|ll|l|l|l|l|l|}
\hline Model & & $\begin{array}{l}\text { Sum of } \\
\text { Squares }\end{array}$ & df & $\begin{array}{l}\text { Mean } \\
\text { Square }\end{array}$ & F & Sig. \\
\hline 1 & $\begin{array}{l}\text { Regre } \\
\text { ssion }\end{array}$ & 791,822 & 2 & 395,91 & 38,274 &, $000^{\mathrm{b}}$ \\
& $\begin{array}{l}\text { Resid } \\
\text { ual }\end{array}$ & 382,734 & 37 & 1 & & \\
& Total & 1174,557 & 39 & 10,344 & & \\
\end{tabular}

a. Dependent Variable: Karyawan

b. Predictors: (Constant), Sistemmanajemen, sdm

source : data output spss

The hypothesis in this study, are as follows:

$\mathrm{HA}=\mathrm{HR}$ competencies simultaneously had a significant influence on performance of employees.

$\mathrm{HA}=$ performance management system had a significant influence on performance of employees.

In testing I used a way of comparing the magnitude of the number F-female with F-table. After calculating the F-female from SPSS acquired for 38.247 and F-table is calculated by a significant extent provisions of 0.05 and degrees of freedom $(\mathrm{dk})$ and the provisions of the numerator (number of variables-1) or $(3-1)=2$; and the denumerator; (number of cases -2 ) or $(40-2)=38$.

After the calculated F-female with F-table further specifies the criteria the following hypothesis tests:

If F-female > F-table, then the Ha received.

If F-female < F-table, then the Ha declined.

From the above calculation, the results retrieved number F-female of $38.247>$ F-table of 2.253 so Ha. That is, the competence of human resources and performance management system had a significant influence on performance of employees. Thus, the regression model above and right. The conclusion is, that the competence of human resources and performance management systems to simultaneously effect significantly to the performance of the employee. The magnitude of the influence is 38.247. The magnitude of the influence of other variables outside of the regression model is calculated by the formula: $(1-\mathrm{r} 2)$ or $(1-$ $0.58)=0.42$ or amounted to $42 \%$.

\section{CONCLUSION}

Based on the results of the analysis and discussion of competency and performance management system on performance of employees at Narita Hotel Surabaya then can be summed up as follows:

1. Based on the hypothesis test results it can be concluded that the variables HR competencies and performance management system may effect on performance of employees at Narita Hotel Surabaya.

2. Based on the determination of rated $R(R)$ of 0821 set transfer- 1 to 1 and $R$ approaches 1 then it can be said that a very strong positive relationship and vice versa. Based on the above table results the coefficient of determination (R2) values Adjusted R Square of 0657, this means $65.7 \%$ employee performance variations can be explained by the independent variable (HR competencies and performance management system) while the rest $(100 \%-65,7 \%=34.3 \%)$ is explained by other reasons outside the model. Here the results of the R2 of $65.7 \%$ means the ability of independent variables in explaining the dependent variables are very high.

\section{LIMITATION}

Restrictions against this research as follows:

1) research Objects are only held at the location of the Hotel Narita Surabaya. Therefore, if there is somewhere else, then it should be linked in this study

2) performance measurement Narita Hotel Surabaya uses three variables are free i.e. HR Competencies and performance management System. If there is a measurement that uses another variable, then it will not be discussed in this research. 


\section{Reference}

[1] D. J. Priansa, Perencanaan dan Pengembangan SDM. Bandung. bandung, 2014.

[2] W. F. Cascio, "Managing human resources," 2013.

[3] J. K. Turangan, "PENGARUH KOMPETENSI, DISIPLIN KERJA DAN PROFESIONALISME TERHADAP KINERJA GURU DI SMA NEGERI 1 MANADO,” 2015.

[4] Management \& Author, "The Effect of Training and Ability on the Performance of Employee at Disaster Management Bureau of Central Kalimantan Province," 2017.

[5] Sugiyono, "Metode Penelitian Kuantitatif, Kualitatif dan R\&D. Bandung: Afabeta.," 2011.

[6] Dharma, kompetensi SDM. 2013.

[7] Moeheriono, kompetensi sdm. spencer, 2014.

[8] Cascio, Performance Management System. 2013.

[9] June Donni Priansa, Employee Performance. Mathis and Jackson, 2014.

[10] Simanjuntak, "Employee Performance," 2005.

[11] Widodo, "Employee Performance," 2015.

[12] I. Ghozali, "Aplikasi Analisis Multivariete Dengan Program IBM SPSS 23,” 2016.

[13] I. Ghozali, "Aplikasi Analisis Multivariate Dengan Program IBM SPSS Group.," 2016.

[14] J. Sarwono, "Jurus Ampuh SPSS Untuk Riset Skripsi. Jakarta.Gramedia," 2013.

[15] I. Ghozali, Normality Test. 2016. 
